\title{
SURADNJA IZMEĐU KNJIŽNICA I \\ CIVILNOGA DRUŠTVA TE NJEZINA ULOGA U MEDIJIMA
}

\author{
THE COOPERATION BETWEEN LIBRARIES \\ AND CIVIL SOCIETY AND THEIR ROLE IN THE MEDIA
}

\section{Ivana Nikolić}

Odsjek za informacijske i komunikacijske znanosti Filozofski fakultet Sveučilišta u Zagrebu ${ }^{1}$ ivanan@post.com

\author{
UDK / UDC \\ 027:323.21:364:[070:316.77] \\ Prethodno priopćenje / Preliminary report \\ Primljeno / Received: 30.8.2017. \\ Prihvaćeno / Accepted: 30.11.2017.
}

\section{Sažetak}

Cilj. Rad analizira suradnju između knjižnica i aktera civilnoga društva koji se bave problematikom beskućništva kao primjer pomoći ugroženim društvenim skupinama. Također utvrđuje koliku je medijsku pozornost tema dobila.

Pristup. Prvi dio rada analizira suradnju između knjižnica i civilnoga društva, naglašavajući potencijale knjižnica i aktivan pristup kako bi se pružila konkretna pomoć potrebitima. Drugi dio rada, kvantitativna analiza sadržaja novinarskih tekstova triju internetskih portala u razdoblju duljem od godine dana, utvrđuje kolika je medijska zainteresiranost za temu.

Rezultati. U konačnici, rezultati pokazuju nedostatnu medijsku zainteresiranost za suradnju između knjižnica i civilnoga društva te problematiku beskućništva općenito. Ipak, zamjetni su pozitivni primjeri koji pokazuju kako su mediji dali svojevrstan poticaj suradnji i doprinijeli rješavanju problema.

1 Istraživanje je provedeno tijekom razdoblja mobilnosti na doktorskom studiju na Filozofskom fakultetu Sveučilišta u Zagrebu, a matični je fakultet Filozofski fakultet Sveučilišta u Mostaru.

Vjesnik bibliotekara Hrvatske 60, 4(2017), 181-196

ISSN 0507-1925

(C) VBH 2017. 
Originalnost/vrijednost. Rad naglašava temelje novinarstva koje je potrebno poštovati kako bi se pridonijelo rješavanju gorućih društvenih problema. U radu je također naglašena važnost strateškoga razmišljanja o ulozi knjižnica, imajući na umu njihovu otvorenost prema ugroženim društvenim skupinama i upotrebu njihovih potencijala za dobrobit cjelokupna društva.

Ključne riječi: civilno društvo, knjižnice, mediji

\begin{abstract}
Purpose. The paper analyzes the cooperation between libraries and civil society actors who deal with the problem of homelessness as an example of providing assistance to vulnerable social groups. It also investigates the level of attention this topic has received in the media.
\end{abstract}

Approach. The first part of the paper analyzes the cooperation between libraries and civil society organizations, emphasizing libraries' potentials and an active approach in providing a concrete help to those who are in need. The second part of the paper presents a quantitative content analysis of the newspapers articles published on the three online news websites during a period of one year, and determines the media interest in the topic.

Results. In conclusion, the results have shown that there is a lack of media interest in the collaboration between libraries and civil society and the problem of homelessness in general. However, there is a number of noteworthy positive examples in which the media gave a reasonable encouragement to this kind of cooperation and contributed to solving the problems.

Originality/value. The paper emphasizes the core principles of journalism that need to be respected in order to contribute to solving the burning social problems. It also emphasizes the importance of strategic thinking about the role of libraries, bearing in mind their openness to vulnerable social groups and the use of their potentials for the benefit of the whole society.

Keywords: civil society, libraries, media

\title{
1.Uvod
}

Neosporna je važnost knjižnica za društvo i njegov cjelokupan razvoj. Knjižnice su i važne, i korisne, i zanimljive ustanove koje sabiru raznoliku građu. U Hrvatskoj enciklopediji knjižnice su prema sadržaju zbirki podijeljene na opće i specijalne, a prema namjeni i korištenju na privatne i javne knjižnice. ${ }^{2}$ Tisućljetni razvoj knjižnica ukazuje na njihovu bogatu povijest, raznoliku baštinu, istraživač-

\footnotetext{
2 Hrvatska enciklopedija: 6: Kn-Mak. Zagreb : Leksikografski zavod „Miroslav Krleža“, 2004. Str. 12.
} 
ko zanimanje za tematiku. Ljudska potreba za komunikacijom povezana je također s razvojem knjižnica i njihovom ulogom u društvu. Razvoj novih tehnologija donio je nesagledive mogućnosti i sve veću dostupnost informacija različitih vrsta, što se odrazilo i na razvoj knjižnica.

Različita su istraživanja glede nastanka knjižnica, njihova razvoja, usluga, pristupa korisniku. ${ }^{3}$ Prema Stipanovu, povijest knjižnica stara je približno koliko i sama povijest. ${ }^{4}$ Općenito razmatrajući, znanstvena literatura također svjedoči o različitim pristupima istraživanja knjižnica, dok se zamjetan broj znanstvenih radova odnosi na središnju ulogu korisnika i njihovih potreba. Promjene koje donose nove tehnologije i zamjetna informatizacija cjelokupna društva također su teme istraživanja.

Današnje je društvo prožeto medijima, u njemu mediji igraju ključnu ulogu i posrednici su između institucije, njezinih korisnika te šire javnosti. Uzimajući u obzir složenost društva i problematiku kojoj svakodnevno svjedočimo, jasna je potreba suradnje između različitih aktera kako bi se pridonijelo rasvjetljavanju i rješavanju društvenih problema te podiglo razinu životne kvalitete, posebno ugroženih društvenih skupina. U tome kontekstu plodonosna može biti suradnja između knjižnica i civilnoga društva, odnosno njihovih aktera. Razvijena društva pokazuju primjere suradnje između knjižnica i udruga za osobe lišene prava na vlastiti dom, odnosno boraca za one koji dom nemaju.

Istraživačko je pitanje ovoga rada kako su mediji u Hrvatskoj predstavili suradnju između knjižnica i aktera civilnoga društva tijekom 2016. i 2017. godine. Je li riječ o temi koja je prisutna u medijima i koju su široj javnosti odlučili predstaviti urednici, odnosno osobe odgovorne za objavu sadržaja i načine njihova prikaza ili pak ne? Zbog specifične uloge knjižnica u društvu i različitih projekata suradnje s civilnim društvom, fokus je ovoga rada na knjižnicama. Analizirani su akteri civilnoga društva pravne i fizičke osobe koje se bave problematikom beskućništva. Naravno, postoje i drugi zanimljivi primjeri suradnje između aktera civilnoga društva i knjižnica, no ovaj rad fokusiran je na goruću problematiku beskućništva. Nastojat će se izbjeći riječ „,beskućnik“ u radu, imajući na umu upozorenja da njezino konotativno značenje može povrijediti osobe bez vlastita doma, što i sami svjedoče. Dakle bit će upotrijebljena riječ „potrebiti“, imajući na umu osobe pogođene gorućim problemima današnjice, odnosno osobe bez doma, osnovnih dokumenata, posla. Kada je riječ o općoj problematici, koristit će se pojam „beskućništvo“.

\footnotetext{
3 Sve imenice muškoga roda u ovome radu (npr. korisnik, znanstvenik, stručnjak) podrazumijevaju i imenice ženskoga roda (korisnica, znanstvenica, stručnjakinja).

4 Usp. Stipanov, J. Knjižnice i društvo - od potrebe do mogućnosti. Zagreb : Školska knjiga, 2010. Str. 26.
} 
Potrebite možemo svakodnevno vidjeti na ulicama, kolodvorima, kod odlagališta otpada, unatoč nezanemarivim kapacitetima različitih institucija. Stoga je još važniji primjer knjižnice kao ustanove koja različitim projektima može pridonijeti rješavanju društvenih problema, doprijeti do šire javnosti, potencijalnih korisnika. U Hrvatskoj su knjižnice po prvi put nagrađene za projekt „Knjigom do krova“ (nagrada „Ponos Hrvatske“ dodijeljena je Knjižnicama grada Zagreba u veljači 2017. i odnosi se na 2016. godinu). Smisao je projekta veća uključenost potrebitih u društvu, veće mogućnosti za pronalazak posla i, konačno, rješenje teške životne situacije.

Glede medija, metodom analize sadržaja analizirani su novinski tekstovi navedene tematike koji su objavljeni na tri internetska portala: 24sata.hr, jutarnji. hr, telegram.hr. Tekstovi su objavljeni u razdoblju od 1. siječnja 2016. do 28. veljače 2017. godine. Dnevne novine, odnosno tabloid 24 sata pokrenut je 2005. godine, a njihov portal 24sata prema istraživanju Gemius Audiencea najčitaniji je u Hrvatskoj. ${ }^{5}$ Dnevne novine Jutarnji list osnovane su 1998. godine te godinama kontinuirano izvještavaju o svakodnevnim događajima, uključujući portal jutarnji.hr, odnosno njihovu elektroničku inačicu. Konačno, telegram.hr pokrenut je 2015. godine i ,najmlađi“ je od analiziranih portala.

Metoda analize sadržaja koristi se za analizu sadržaja različite vrste. „Obilježja koja analizi sadržaja pridaju gotovo sve definicije jesu objektivnost, sustavnost i općenitost. ${ }^{\text {" }}$ Njezina suvremena upotreba služi kvantificiranju podataka, a svojstvena joj je i višestruka i dugotrajna primjena. Analiza je obuhvatila novinarske tekstove objavljene tijekom cjelokupne 2016. te siječnja i veljače naredne godine budući da su na internetskim portalima početkom 2017. objavljeni novinarski tekstovi na temu iznimno niskih temperatura i zabilježenih smrtnih slučajeva, što se posebno odnosi na problematiku beskućništva. Također, nagrada za projekt „Knjigom do krova“ dodijeljena je Knjižnicama grada Zagreba u veljači i zanimljivo je analizirati kako su mediji predstavili tematiku javnosti. Nakon uvoda, razmatra se uloga knjižnica u društvu, uloga medija u društvu, suradnja između knjižnica i aktera civilnoga društva. Potom slijede metodologija, analiza rezultata i zaključak. Teza je rada da je suradnja između knjižnica i civilnoga društva u konkretnome slučaju ovoga rada medijski podzastupljena.

\section{Uloga knjižnica u društvu}

Knjižnična djelatnost zakonski je regulirana, a propisi koji se odnose na knjižničnu djelatnost prvenstveno navode Zakon o knjižnicama. Zastupnički dom

\footnotetext{
5 Usp. Rating Gemius. [citirano: 2017-04-26]. Dostupno na: https://rating.gemius.com/hr/tree/ domains.

6 Milas, G. Istraživačke metode u psihologiji i drugim društvenim znanostima. Jastrebarsko : Naklada Slap, 2005. Str. 501.
} 
Sabora Republike Hrvatske donio je Zakon o knjižnicama 1997. godine. Osim kratkoga ispravka Zakona koji je izdan 1998., poznata je i Odluka o proglašenju Zakona o izmjenama i dopunama Zakona o knjižnicama, prva iz 2000., a druga iz 2009. godine. Glede Odluke iz 2000., članak 3. Zakona o knjižnicama dopunjen je stavkom 3. i odnosi se na zadaću knjižnica:

„Zadaća knjižnica je da u ostvarivanju javne službe nastoje zadovoljiti obrazovne, kulturne i informacijske potrebe svih građana na području svoga djelovanja te da promiču čitanje i druge kulturne aktivnosti u cilju unapređivanja ukupnoga kulturnoga života zajednice."

Podrobnija definicija zadaća knjižnica također ide u prilog njihovoj važnosti u društvu. Prepoznato je i da knjižnice raspolažu potencijalom koji može biti višestruko korišten. Drugim riječima, knjižnica nije tek puka ustanova ili zanimljiv primjer arhitekture prepušten stihijskomu razvoju, nego svojevrsna mreža kapaciteta koji nalažu strateško razmišljanje i strateške odluke.

Obrazovne, kulturne i informacijske potrebe građana višestruko su povezane s knjižnicama koje imaju nezaobilazno mjesto u društvu i pokazatelj su razvijenosti određene sredine. Razvoj knjižnica ujedno doprinosi razvoju pojedinaca i društva u cjelini. U knjižnicama se okupljaju osobe koje traže znanje, koriste knjige kako bi naučile više, sudjeluju u različitim kulturnim aktivnostima. Nevisno o vrsti potrebe, posebno je važna pristupačnost informacija koju knjižnična djelatnost također obuhvaća prema članku 6. Zakona o knjižnicama. ${ }^{8}$

Knjižnica (riječ „knjižnica” ili bibliotheca dolazi od riječi „knjiga” i odnosi se na „skup, odnosno zbirku knjiga" ) je definirana i kao „društvena agencija”, „kulturna ustanova”" jižničarstvo je suočeno sa značajnim promjenama. ${ }^{13}$ Promjene su vidljive glede prikupljanja različitih informacija, njihove pohrane i dostupnosti, a poseban je naglasak na korisniku kao pojedincu i njegovim potrebama. Današnje knjižnice

\footnotetext{
7 Zakon o izmjenama i dopunama Zakona o knjižnicama. // Narodne novine 2040, 104(2000). [citirano: 2017-10-20]. Dostupno na: https://narodne-novine.nn.hr/clanci/sluzbeni/2000_10_104_2040.html.

8 Zakon o knjižnicama. // Narodne novine 1616, 105(1997). [citirano: 2017-10-20]. Dostupno na: https://narodne-novine.nn.hr/clanci/sluzbeni/1997_10_105_1616.html.

9 Stipanov, J. Nav. dj., str. 11. Stipanov također na istoj stranici objašnjava da su riječi „knjiga“ $\mathrm{i}$ „knjižnica“ dobile naziv prvenstveno po svome fizičkom izgledu, a ne sadržaju, odnosno znanju.

10 Isto, str. 14.

11 Belan-Simić, A.; I. Đukec Kero. Strateško planiranje i javnozagovaračke aktivnosti Knjižnica grada Zagreba. // Vjesnik bibliotekara Hrvatske 58, 1/2(2015), str. 31.

12 Stipanov, J. Nav. dj., str. 18.

13 Usp. Živković, D. Knjižnice na putu od poslanja do strategije: osvrt na hrvatske prilike. // Vjesnik bibliotekara Hrvatske 58,1/2(2015), str. 2.
} 
opremljene su u duhu vremena i nude različite mogućnosti svojim korisnicima (posudba knjiga, rad u knjižnici, posudba računalne opreme, rad na internetu, pretraživanje kataloga). Glede korisnika i komunikacije, nezanemarivo mjesto zauzimaju mediji budući da putem njih korisnici dobivaju informacije o radu društvenih ustanova.

\section{Uloga medija u društvu}

Medijima je dodijeljena neosporna uloga u društvu. Mediji kontinuirano izvještavaju javnost o različitim temama, kao i o radu različitih društvenih institucija. Štoviše, u slučaju nedostatka ili manjka vlastitih komunikacijskih kanala, mediji mogu postati ili se nametnuti kao glavni prijenosnik obavijesti o radu određene institucije, agencije ili udruge. Stoga su mediji u fokusu institucija koje ne zanemaruju njihovu ulogu u društvu.

Pojam medija definiran je na različite načine i u različitim kontekstima. Zakon o medijima također navodi različite medije u članku $2^{14}$ (od tiskovina, radijskih i televizijskih programa, pa sve do drugih oblika programskih sadržaja). Različiti autori bilježe važne napomene kada je riječ o definicijama medija. Mediji nisu tek tehnologija za prijenos sadržaja, nego aktivno sudjeluju u konstrukciji cjelokupne realnosti. ${ }^{15} \mathrm{Uz}$ svojevrsne klasične medije (novine, radio, televiziju), pojava interneta omogućila je veću uključenost i angažiranost korisnika glede medijskih sadržaja te određeni autori naglašavaju razliku između klasičnih i novih medija.

Tako primjerice Kunczik i Zipfel navode da je interaktivnost nezaobilazna karakteristika novih medija. ${ }^{16}$ Autori također pišu o svojevrsnoj utopiji koju je izazvala pojava interneta, posebno na području politike. ${ }^{17}$ No praksa bilježi primjere u kojima medijske ustanove, odnosno njihovi čelni ljudi i dalje dominantno odlučuju o medijskim sadržajima koje će objaviti i na koji način, a bilježi i primjere marginaliziranosti korisnika koji su svedeni na razinu pasivne publike, medijskih konzumenata i potrošača.

Ne izostaju kritike medija imajući na umu brojne dezinformacije i različite trivijalnosti koje se njima prenose. Važno je naglasiti zamjetan fokus medija na vulgarnostima, niskim strastima, mediokritetu. ${ }^{18}$ Odabir tema, sklonost određenim

\footnotetext{
14 Zakon o medijima. // Narodne novine 1324, 59(2004). [citirano: 2017-04-26]. Dostupno na: http://narodne-novine.nn.hr/clanci/sluzbeni/2004_05_59_1324.html.

15 Usp. Hromadžić, H. Mediji i spektakularizacija društvenog svijeta. Masmedijska produkcija „kulture slavnih“. // Filozofska istraživanja 120, 30(2010), str. 619.

16 Usp. Kunczik, M.; A. Zipfel. Uvod u znanost o medijima i komunikologiju. Zagreb : Zaklada Friedrich Ebert Stiftung, 2006. Str. 28-29.

17 Usp. isto, str. 64.

18 Usp. Bal, F. Moć medija. Beograd : Clio, 1997. Str. 14.
} 
načinima prikaza tematike $\mathrm{i}$ ignoriranje društveno važne problematike svjedoče o vjerodostojnosti medija. Neophodno je naglasiti vjerodostojnost medija i njihovu primarnu odgovornost, a ona podrazumijeva službu na dobrobit naroda. ${ }^{19}$ Društvena uloga medija također je neosporna, no nameće se pitanje zašto zamjetan broj medija ignorira određene teme ili ih tendenciozno kontekstualizira te što navedeno govori o vjerodostojnosti medija. Na temelju zakonskih odredbi, pravila struke i profesionalnih standarda mediji također podliježu odgovornosti za vlastiti rad. Neistinito izvještavanje javnosti, dezinformacije i klevete imaju dalekosežne posljedice za pojedinca, njegovu obitelj i društvo u cjelini. Rad novinara pokazatelj je njegova integriteta i vjerodostojnosti.

Nažalost, kritike upućene medijima iznimno su česte, kao i zapažanja da je novinarstvo zamjetno ispod standarda profesionalnosti, a novinarima se ne može vjerovati. Iznimke postoje. Prisutni su i pozitivni primjeri u medijskoj praksi. Primjeri dobre prakse iznimno su potrebni budući da mediji istinitim i profesionalnim izvještavanjem, koje je njihova zakonska obveza i profesionalni imperativ, mogu doprinijeti rasvjetljavanju određene problematike i rješavanju gorućih društvenih problema.

Uzimajući u obzir važnost medija u društvu, društvenu ulogu knjižnica te društvenu problematiku oko koje su posebno angažirani akteri civilnoga društva, istraživački je izazov analizirati medijsku predstavljenost suradnje između knjižnica i civilnoga društva. Drugim riječima, cilj je odgovoriti na pitanje kako su navedeni internetski portali tijekom 2016. i 2017. godine izvještavali o suradnji između knjižnica i aktera civilnoga društva glede problematike potrebitih, odnosno osoba koje nemaju realizirane osnovne životne uvjete.

\section{Suradnja između knjižnica i civilnoga društva}

Pojam civilnoga društva podrazumijeva suradnju između različitih aktera s ciljem rješavanja različitih problema i niza društvenih situacija. Prema Šalaju, glavni su akteri civilnoga društva nevladine organizacije. ${ }^{20}$ Činjenica je da civilno društvo čine različiti akteri, više ili manje aktivni i poznati široj javnosti, no raspon je njihova djelovanja mnogostruk. Doprinos civilnoga društva odražava se u aktivnostima glede bolje artikulacije i rješavanja problema, kritike vlasti, povezivanja s ciljem veće dobrobiti društva. ${ }^{21}$

Akteri civilnoga društva mogu potaknuti i realizirati korisne društvene inicijative te biti partner za plodonosnu suradnju. S akterima civilnoga društva surađuju

19 Usp. Bertrand, C. J. Deontologija medija. Zagreb : ICEJ i Sveučilišna knjižara, 2007. Str. 10.

20 Usp. Šalaj, B. Civilno društvo i demokracija: što bi Tocqueville i Putnam vidjeli u Hrvatskoj? // Anali Hrvatskog politološkog društva 8(2011), str. 49.

${ }_{21}$ Usp. isto, str. 50. 
i knjižnice. Uslijed različitih promjena u širem društvu, uloga knjižnica postaje sve dalekosežnija. Izrazit je naglasak stavljen na korisnika i njegove potrebe, čijoj realizaciji pridonose i različite tehnologije, a knjižnice mogu pokazati inovativnu praksu i glede pomoći u rješavanju aktualne društvene problematike.

Različiti su primjeri inovacija u knjižnicama, a suradnja između knjižnica i aktera civilnoga društva također je jedan od njih. Inovacije na području knjižnica pokazatelj su njihova razvoja kroz povijest te veće ili manje kvalitete usluga, ovisno o potrebama određene sredine. Inovativnost podrazumijeva i reakcije na probleme $u$ društvu, angažman glede životne kvalitete i aktivan pristup. ${ }^{22}$

Primjer koji se može navesti jest projekt „Knjigom do krova“" ${ }^{\text {“23 }}$, tijekom kojega su potrebiti pronašli svojevrsno utočište u knjižnicama. Putem aktivnosti projekta omogućeno im je da se uključe u društvo, razvijaju i usavršavaju radne mogućnosti, povećavaju mogućnosti za pronalazak posla te time i pronađu rješenja iznimno nelagodnih životnih situacija. Primjer aktivne uloge knjižnica na tome području poznat je u razvijenim sredinama gdje se knjižnice i njihovi kapaciteti koriste za pomoć potrebitima te doprinose razvoju cjelokupnog društva. Različite udruge kao dio civilnoga društva u svome radu surađuju s medijima. Putem njih mogu prenijeti informacije o vlastitim aktivnostima, projektima $\mathrm{i}$ mogućnostima potpore široj javnosti. No zamjetno je i da su često medijski ignorirane, a može se navesti i svojevrsna medijska nezainteresiranost za njihove aktivnosti.

Prema rezultatima istraživanja „Procjena stanja razvoja organizacija civilnoga društva u Hrvatskoj“ iz 2011. godine, postoji nezainteresiranost medija za aktivnosti udruga. Iako postoje primjeri suradnje, naglašen je prvenstveno problem nezainteresiranosti. ${ }^{24}$ Budući da mediji služe kako bi informirali javnost o društveno relevantnoj tematici, nameće se pitanje zašto relevantne informacije ipak izostaju. Različita istraživanja na višestrukim primjerima ukazuju na važnost informiranja i veće uključenosti javnosti ${ }^{25}$ zbog razvoja njezina kritičkoga stava, suradnje u planiranju, odlučivanju i rješavanju društvenih problema.

22 Usp. Sabolović-Krajina, D. Inovativnost u knjižnicama: primjer prakse knjižnice i čitaonice „Fran Galović“ Koprivnica. // Vjesnik bibliotekara Hrvatske 58, 1/2(2015), str. 317.

23 Bunić, S. „Knjigom do krova“ i knjižnice su Ponos Hrvatske (19.02.2017.). // Knjižnice grada Zagreba. [citirano: 2017-10-13]. Dostupno na: https://beskucnik.kgz.hr/ostalo/knjigomdo-krova-i-knjiznice-su-ponos-hrvatske/; također, Culturenet.hr. Knjigom do krova: mreža knjižnica za osnaživanje beskućnika. [citirano: 2017-10-13]. Dostupno na: http://www.culturenet.hr/default.aspx?id=41049.

${ }^{24}$ Usp. Plavša-Matić, C. Procjena stanja razvoja organizacija civilnoga društva u Republici Hrvatskoj: izvještaj istraživanja u 2011. godini. Zagreb : Nacionalna zaklada za razvoj civilnoga društva, 2012. Str. 106.

25 Usp. Pavić-Rogošić, L. Imaju li građani što za reći? Sudjelovanje organizacija civilnog društva u donošenju odluka na lokalnoj razini. Zagreb : ODRAZ, 2012. Str. 67. 


\section{Istraživanje}

\subsection{Cilj istraživanja}

Cilj je istraživanja dobiti uvid u suradnju između knjižnica i aktera civilnoga društva na konkretnome primjeru suradnje između knjižnica i aktera civilnoga društva te ustanoviti koliki je medijski interes za tu temu. Budući da mediji itekako mogu skrenuti pozornost javnosti na teme o kojima izvještavaju i posljedično pridonijeti rješavanju važnih društvenih problema, nameće se pitanje koliko je i na koji način tema suradnje između knjižnica i civilnoga društva u konkretnome slučaja ovoga rada prisutna u medijima.

\subsection{Metodologija}

Metoda analize sadržaja primjenjuje se i kada je riječ o novinarskim tekstovima objavljenim u različitim medijima: novinama, njihovim elektroničkim inačicama, novinarskim tekstovima na temelju kojih nastaju televizijski prilozi itd. Važno je razlikovati kvalitativnu od kvantitativne analize sadržaja. Nefrekvencijskom ili kvalitativnom analizom sadržaja ,(...) otkriva se i bilježi određeni sadržaj te se analiziraju obilježja tog sadržaja (,što' i ,kako').“26 Uz, što' i ,kako', frekvencijska ili kvantitativna analiza sadržaja ujedno daje odgovor na pitanje ,koliko', odnosno daje konkretne podatke o frekvenciji sadržaja. ${ }^{27}$ Kvalitativna analiza sadržaja može značajno koristiti za prikupljanje podataka, no često se primjenjuje zajedno s drugom istraživačkom metodom, odnosno metodama. Praksa također pokazuje da se u znanstvenim radovima kombinirano koriste kvantitativna i kvalitativna analiza sadržaja.

Slijedeći pravila postupka analize sadržaja, odabran je uzorak za analizu koji čini ukupno 100 novinarskih tekstova (24sata.hr: 45, jutarnji.hr: 33, telegram. $h r: 22$ teksta) koji se odnose na problematiku beskućništva i njezina moguća rješenja, odnosno suradnju između knjižnica i aktera civilnoga društva. Novinarski tekstovi objavljeni su na portalu 24 sata, Jutarnjega lista i Telegrama u razdoblju od 1. siječnja 2016. do 28. veljače 2017. godine. Analizirani su dostupni tekstovi navedene tematike objavljeni na internetskim portalima tijekom 14 mjeseci i već je uzorak pokazatelj njezine zamjetne medijske podzastupljenosti budući da primjerice različite analize tekstova političke tematike mogu obuhvatiti veći uzorak jednostavno zbog većega broja objavljenih tekstova.

Jedinica je analize novinarski tekst. Analiza nije obuhvatila eventualne videosadržaje ili pak preslike objava na društvenim mrežama koje su dodane u novi-

\footnotetext{
26 Usp. Tkalac Verčić, A.; D. Sinčić Ćorić; N. Pološki Vokić. Priručnik za metodologiju istraživačkog rada. Zagreb : M.E.P. d.o.o., 2010. Str. 92.

27 Isto.
} 
narske tekstove. Kategorije matrice odnose se na opće karakteristike novinarskih tekstova, pristup problematici, naslove i grafičku opremu. Drugim riječima, analiza je usmjerena na izvor informacije (imenovani i neimenovani), autora, rubriku, komentar novinara, način prikaza problematike, prisutnost ili odsutnost spomena suradnje između knjižnica i civilnoga društva u svrhu poboljšanja životne situacije potrebitih, vrstu naslova, upotrebu negativnih, pogrdnih ili prozivajućih izraza u naslovu, vrstu grafičke opreme, na to koga ili što grafička oprema prikazuje te na način prikaza.

\subsection{Analiza rezultata}

Glede rezultata, u slučaju tematike ovoga rada može se navesti, imajući na umu cjelokupan kontekst, da su neki od rezultata očekivani. S druge strane, zabrinjavajući postoci ukazuju na nužnost reakcija i promjena na dobrobit novinarstva $\mathrm{i}$ društva u kojem djeluje. Naime $\mathrm{u}$ analiziranim je tekstovima novinarski izvor podataka u samo $2 \%$ slučajeva osoba iz područja knjižnica. Glede navedenih 2 \% slučajeva, novinarski je izvor u svima njima knjižničar/ka. Novinarski izvori ključna su odrednica. Zamjetno je da su stručne osobe dobile jako malo medijskoga prostora, što se odrazilo i na sadržaj upućen javnosti.

Rezultati pokazuju kritične postotke i kada je riječ o akterima civilnoga društva. U samo $6 \%$ analiziranih tekstova izvor je osoba iz civilnoga društva (primjerice udruga ili osoba koja se bavi problematikom beskućništva i sl.). Potrebiti (bilo da je riječ o sadašnjosti ili prošlosti) su izvor informacija u $36 \%$ analiziranih novinarskih tekstova. Dok je vidljivo da smo preplavljeni različitim trivijalnostima putem medija, na što upozorava i nezanemariv broj istraživanja medijskih sadržaja, svakodnevno susrećemo „vijesti“ u kojima su kao izvori predstavljene osobe koje to i ne zaslužuju svojim radom, stručnošću, životnim situacijama. Umjesto prisutnosti stručnjaka u medijima, koji imaju što reći i mogu pomoći u rješavanju gorućih problema kojima je pogođen sve veći broj ljudi, korisnici medija preplavljeni su skandalima, često političke ili seksualne naravi.

Nadalje, problematika beskućništva spominje se u $85 \%$ analiziranih tekstova. Postotak je velik, no također je važno uzeti u obzir da se u $69 \%$ tekstova ne spominje mogući način rješavanja problematike. Dodajmo tomu da se u samo 2 $\%$ analiziranih tekstova spominje suradnja između knjižnica i civilnoga društva u svrhu poboljšanja životne situacije potrebitih i njihovih osnovnih životnih uvjeta, čije ispunjenje omogućuje dostojanstven život. Hipoteza jest potvrđena, suradnja između knjižnica i civilnoga društva u slučaju ovoga rada iznimno je medijski podzastupljena, no nema mjesta zadovoljstvu imajući na umu dosegnutu razinu profesionalnosti, društvene osviještenosti i angažiranosti medija.

Komentar novinara može se prepoznati u $61 \%$ analiziranih tekstova. Naravno da teorija i praksa poznaju oblike novinarskoga izražavanja u kojima novinar 
može iznijeti komentar na određenu temu, vlastita zapažanja ili dojmove. No profesionalna je obveza jasno navesti da je riječ o komentaru (koji ne mora biti točan) i ne predstavljati komentar kao vijest, i to, štoviše, udarnu vijest. „Teoretičari vrlo jasno ističu kako tu nema dvojbe: vijest se temelji na točnim podacima i ona predstavlja istinu. “" ${ }^{\text {"28 }}$ Primjerice kolumna je prihvaćen subjektivniji oblik izražavanja u kojem ipak u pravilu nema mjesta za svakakve komentare budući da neutemeljeni, uvredljivi i vulgarni komentari provociraju ozbiljne reakcije i govore o samomu autoru. Između komentara i vijesti kao glavnoga oblika novinarskoga izražavanja postoji značajna i nezanemariva razlika.

Glede naslova novinarskih tekstova, čitatelj može samo na njih obratiti pozornost, a da i ne pročita tekst ili uopće ne „klikne“ na njega. Naslovima se u novinarstvu pridaje velika pozornost, posebno odabiru riječi unutar naslova. U 46 $\%$ analiziranih tekstova karakter je naslova negativan. Novinari žele privući pozornost, no pridonose li uistinu informiranosti i, u konačnici, dobrobiti svojih korisnika ukoliko ih šokiraju, provociraju, sablažnjavaju i pozivaju na niske strasti?

Potrebiti su, neovisno o stvarnim razlozima zbog kojih su se našli na ulicama, predstavljeni u medijima kroz naglašenu negativnost, emocije, senzacionalne obrate („od beskućnika do zvijezde“), pojedinačne akcije ovisne o dobroj volji i samilosti pojedinaca. Pomoć potrebitima od strane voljnih pojedinaca za svaku je pohvalu, no potrebno je dodati da nije riječ o sustavnim rješenjima i strateškom promišljanju koje će donijeti dalekosežnije korisne društvene promjene. U novinarskim tekstovima prepoznate su i predrasude glede potrebitih, primjerice da su svi narkomani, besposličari, kriminalci ili jednostavno nesretni ljudi i više se ništa ne može poduzeti. Drugim riječima, rješenja nema. Kapaciteti odgovarajućih ustanova nisu dovoljno prepoznati, a ni korišteni. Slijede neki od primjera iz analiziranih tekstova. Naravno, budući da je iznimno malo primjera tekstova sa stručnjacima kao izvorima, takvi primjeri i ne mogu biti navedeni.

Dragutin Todorčević (64), beskućnik koji je umro u strašnim mukama nakon što ga je zapalio dječak (12) je pomagao bolesnoj djeci. Dragutinova životna priča bila je tužna i teška. (24 sata, 15. 12. 2016.)

Policija je potvrdila da dvanaestogodišnjak ne podiježe kaznenoj odgovornosti te je pušten iz policije nakon što su s njim obavili razgovor. (24 sata, 14. 12. 2016.)

Prema svemu sudeći brojni prolaznici i okolni stanari i dalje će strahovati da im neki dio zgrade ne padne na glavu, trpjeti smrad smeća i strahovati od požara kojih je bilo u više navrata jer je prostor, čija

28 Malović, S. Osnove novinarstva. Zagreb : Golden marketing; Tehnička knjiga, 2005. Str. 19. 
unutrašnjost podsjeća iz postapokaliptičnih filmova, okupljalište beskućnika i narkomana. (Jutarnji, 26. 8. 2016.)

Prema pisanju Jutarnjeg lista, novac je na kraju znao biti prefakturiran i u tvrtke beskućnika koje su okrivljenici nalazili da figuriraju kao direktori, a zapravo nisu imali nikakve formalne ovlasti u tvrtkama. (Telegram, 25.11.2016)

Primjeri novinarskih naslova:

SUDBINE

ISPOVIJESTI HRVATSKIH BESKUĆNIKA: KAKO SE NOSE S EKSTREMNOM ZIMOM Potresne priče iz prihvatilišta, u jednom je i jedna cijela obitelj s osmero djece (Jutarnji, 16. 1.2017.)

ZAVRŠIO NA ULICI

'NAZIVAO SAM IH LJUDSKIM SMEĆEM, A POSTAO SAM JEDAN OD NJIH Ispovijest bankarova sina koji je odrastao u luksuznom domu, a onda postao beskućnik (Jutarnji, 22. 11. 2016.)

Kriminal na zagrebačkoj veletržnici: 'Prodaju nam voće i povrće ukradeno od sirotinje i beskućnika u Caritasu` (Telegram, 8. 2. 2016.)

Nakon što sam cijeli život radila kao novinarka, postala sam beskućnica. Samo me dvije stvari drže na životu (Telegram, 30. 9. 2016.)

Beskućnik: 'Lažem koliko sam star jer želim mlađe djevojke` (24 sata, 6. 1. 2017.)

Beskućnik je pomagao bolesnoj djeci, a zapalio ga dječak (12) (24 sata, 15. 12. 2016.)

Analiza novinarskih tekstova pokazala je i primjere dobre prakse, iako je njihov postotak znatno manji. Ipak, primjetan je trud novinara koji prate problematiku, a može se prepoznati i nekoliko novinara koji su o njoj kontinuirano izvještavali tijekom vremenskoga razdoblja koje je analiza obuhvatila. Korištenje kapaciteta knjižnica za računalno osposobljavanje potrebitih i njihova priprema za tržište rada s ciljem ostvarenja prava na dom nije posve medijski ignorirana. U tim slučajevima može se prepoznati i važna društvena uloga knjižnica koje se također prilagođavaju promjenama unutarnje i vanjske sredine, analiziraju svoje 
prednosti i nedostatke. Pravilan razvoj podrazumijeva i ispravnu strategiju. U literaturi je naglašena važnost strateškoga promišljanja i planiranja. ${ }^{29}$

Slijede primjeri dobre prakse novinarskoga izvještavanja koje ne uključuje samo prikaz problematike i svojevrsno zgražanje nad njom, nego i navodi moguća rješenja, pristupa proaktivno, uključuje stručnjake kao izvore informacija i prepoznaje društveno korisne projekte.

Projekt `Knjigom do doma`osmislila je knjižničarka Sanja Bunić, uz potporu Knjižnica grada Zagreba. Osim računalnih radionica, organizira druženja s beskućnicima, razna događanja u kojima oni aktivno sudjeluju, doniraju knjige prihvatilištima za beskućnike, a puno pozornosti posvećuju rušenju predrasuda o beskućnicima. Cilj projekta je uključivanje beskućnika u društvena i kulturna zbivanja. (24 sata, 25. 1. 2017.)

Sanji je u ostvarenju projekta puno pomogao Drago Rendulić (52), nekad i sam beskućnik.

- Upoznali smo se u volonterskom centru Zagreb dok sam volontirala i Drago je poželio doći kod nas na informatičke radionice, pa sam ga pozvala na one za treću dob jer nije bilo druge prikladneobjasnila je Sanja. (24 sata, 25. 1. 2017.)

Reporteri Jutarnjeg u četiri najveća hrvatska grada s ljudima koji se najteže nose s ekstremnom zimom.

Koliko često se sjetimo onih koji će zbog hladnoće jedva preživjeti zimu? (...) Zbog ekstreme hladnoće mnoga su hrvatska prihvatilišta posljednjih dana popunila svoje kapacitete. (Jutarnji, 16. 1. 2017.)

- Četiri petine beskućnika nikada nećete vidjeti, ne spavaju na ulici, imaju neki privremeni smještaj. Imaju izuzetno složene probleme koji se tiču mentalnog i fizičkog zdravlja, te obiteljske i emocionalne probleme. Ti ljudi su dosegnuli dno i obično ne znaju gdje se obratiti za pomoć. (Jutarnji, 22. 11. 2016., izvor: osoba o iskustvu beskućništva)

Do sada su supermarketi takvu hranu (op. neprodanu) zalijevali izbjeljivačem, a ukoliko i dalje nastave s takvom praksom prijeti im zakonska kazna od 75 tisuća eura ili dvije godine zatvora. (Telegram, 6. 2. 2016. - donacija neprodane hrane potrebitima)

Postoji mnogo uobičajenih, ali zastarjelih mitova koji opisuju beskućnike, kao na primjer da su to drogeraši, lijenčine, mentalno bo-

29 Usp. Belan-Simić, A.; I. Đukec Kero. Nav. dj., str. 30. 
lesni ili da su se sami odlučili na takav život. No to ne opisuje mene niti većinu ljudi koje sam srela. Mi nismo odabrali ovakav život. (Telegram, 30. 9. 2016.)

Knjižnice upućuju na dosegnuti stupanj kulturnoga razvoja. ${ }^{30}$ Knjižnice su također pokazatelj cjelokupne zrelosti društva, posebno kada je riječ o potrebitima, marginaliziranim i ugroženim društvenim skupinama. No potrebna je i potpora knjižnicama od strane istoga društva, posebno u vremenu naglih i stalnih promjena, sve većih zahtjeva i imperativa brzine. Ukoliko su ključne ustanove zanemarene, vidljive su posljedice za cjelokupno društvo i potrebno je uložiti dodatni napor za zadovoljenje društvenih potreba. ${ }^{31}$

Društvo koje brine za svoje ustanove može višestruko prosperirati budući da smisleno ulaganje donosi višestruke koristi. Broj korisnika knjižnica također varira, a općenita je težnja da on što više raste i da se privuku potencijalni korisnici. Primjerice društvene skupine s posebnim potrebama također su korisnici knjižnica ili će postati korisnici, a knjižnica im može pomoći svojim uslugama i zadržati njihovo članstvo. Naglašena je važnost smjernica zbog unapređenja kvalitete usluge koja se pruža korisnicima. ${ }^{32}$ Dakle smjernice su nužne i za različite slučajeve osjetljivih i ugroženih skupina. Plodonosne su uz dosljednu i kontinuiranu primjenu u praksi. Poseban je fokus na važnosti strategije.

\section{Zaključak}

Strategija je ključan dokument mnogostruke primjene, što vrijedi i za područje knjižnica. Nužno je strateško promišljanje u koje je potrebno uključiti pomoć potrebitima, u slučaju ovoga rada osobama koje su lišene prava na dom. Knjižnica raspolaže potrebnim kapacitetom, njezina je uloga u društvu neosporna i može plodonosno djelovati putem različitih društveno korisnih projekata. Provedena analiza sadržaja pokazala je da mediji, kao današnji ključni posrednici informacija o različitim ustanovama i društvu općenito, ne prepoznaju (ili ne žele prepoznati) i korisnu, i konstruktivnu, i zanimljivu ulogu knjižnica u društvu. Suradnja između knjižnica i civilnoga društva podzastupljena je tema na internetskim portalima u Hrvatskoj kroz cjelokupnu 2016. i početak 2017. godine. Ni činjenica da su knjižnice prvi put nagrađene zbog potpore potrebitim društvenim skupinama nije pretjerano zainteresirala medije, vidno više orijentirane na skandale, tračeve i detalje iz privatnih života pojedinaca kojima kontinuirano daju publicitet. Izjave

\footnotetext{
30 Usp. Stipanov, J. Nav. dj., str. 7.

31 Usp. Kovačević, J.; R. Vrana. Pogled na knjižnične usluge iz perspektive korisnika. // Vjesnik bibliotekara Hrvatske 58, 1/2(2015), str. 157-158.

32 Usp. Šupe, T.; D. Živković. Knjiga i čitanje u slijepe i slabovidne djece. // Vjesnik bibliotekara Hrvatske 57, 4(2014), str. 262.
} 
stručnjaka dobile su iznimno malo medijskoga prostora, a riječ je o ljudima koji imaju što poručiti i pokazuju kako djelovati na veću dobrobit društva.

$\mathrm{Na}$ temelju provedene analize, zabrinjavajuće niskih postotaka uključenosti stručnjaka kao izvora informacija, naglaska na problemima bez prikaza ikakva rješenja, novinarskih komentara i opće negativnosti koja se također odražava u naslovima, može se zaključiti da mediji, odnosno analizirani internetski portali itekako mogu biti angažiraniji kada je riječ o podršci suradnji između knjižnica i aktera civilnoga društva u Hrvatskoj sa svrhom informiranja javnosti, rasvjetljavanja problematike i mogućih rješenja.

Analiza je pokazala i primjere dobre prakse, novinarske tekstove kojima je tema približena javnosti na profesionalniji način, u kojima su navedeni izvori i rješenja te koji ne potiču niske strasti, nego osviještenost vlastitih korisnika. Istraživanja čija je svrha veća osviještenost glede goruće društvene problematike, posebno kada pokazuju i moguća rješenja te mogu doprijeti do šire javnosti, potrebna su i daju svoj dio doprinosa u izgradnji i razvoju društva.

\section{LITERATURA}

Bal, F. Moć medija. Beograd : Clio, 1997.

Belan-Simić, A.; I. Đukec Kero. Strateško planiranje i javnozagovaračke aktivnosti Knjižnica grada Zagreba. // Vjesnik bibliotekara Hrvatske 58, 1/2(2015), 29-44. Dostupno i na: http://hrcak.srce.hr/index.php?show=clanak\&id_clanak_jezik=211854 [citirano: 2017-04-26].

Bertrand, C. J. Deontologija medija. Zagreb : ICEJ i Sveučilišna knjižara, 2007.

Bunić, S. „Knjigom do krova“ i knjižnice su Ponos Hrvatske (19.02.2017.). // Knjižnice grada Zagreba. [citirano: 2017-10-13]. Dostupno na: https://beskucnik.kgz.hr/ostalo/knjigom-do-krova-i-knjiznice-su-ponos-hrvatske/

Culturenet.hr. Knjigom do krova: mreža knjižnica za osnaživanje beskućnika. [citirano: 2017-10-13]. Dostupno na: http://www.culturenet.hr/default.aspx?id=41049.

Faletar Tanacković, S.; B. Badurina. Suradnja baštinskih ustanova u Hrvatskoj : stanje i očekivanja. // 13. seminar Arhivi, knjižnice, muzeji: mogućnosti suradnje u okruženju globalne informacijske infrastrukture / uredile Mirna Willer i Sanjica Faletar Tanacković. Zagreb : Hrvatsko knjižničarsko društvo, 2010. Str. 30-61.

Hromadžić, H. Mediji i spektakularizacija društvenog svijeta. Masmedijska produkcija „kulture slavnih“. // Filozofska istraživanja 120,30(2010), 617-627. Dostupno i na: http:/hrcak.srce.hr/index.php?show=clanak\&id_clanak_jezik=102384 [citirano: 2017-04-27].

Hrvatska enciklopedija: 6: Kn-Mak. Zagreb : Leksikografski zavod „Miroslav Krleža“, 2004. 
Kovačević, J.; R. Vrana. Pogled na knjižnične usluge iz perspektive korisnika. // Vjesnik bibliotekara Hrvatske 58, 1/2(2015), 135-160. Dostupno i na: http://hrcak.srce.hr/ index.php?show=clanak\&id_clanak_jezik=211870 [citirano: 2017-04-26].

Kunczik, M.; A. Zipfel. Uvod o znanost o medijima i komunikologiju. Zagreb : Zaklada Friedrich Ebert Stiftung, 2006.

Malović, S. Osnove novinarstva. Zagreb : Golden marketing; Tehnička knjiga, 2005.

Milas, G. Istraživačke metode u psihologiji i drugim društvenim znanostima. Jastrebarsko : Naklada Slap, 2005.

Pavić-Rogošić, L. Imaju li građani što za reći? Sudjelovanje organizacija civilnog društva u donošenju odluka na lokalnoj razini. Zagreb : ODRAZ, 2012.

Plavša-Matić, C. Procjena stanja razvoja organizacija civilnoga društva u Republici Hrvatskoj: izvještaj istraživanja u 2011. godini. Zagreb : Nacionalna zaklada za razvoj civilnoga društva, 2012.

Rating Gemius. [citirano: 2017-04-26]. Dostupno na: https://rating.gemius.com/hr/tree/ domains.

Sabolović-Krajina, D. Inovativnost u knjižnicama: primjer prakse knjižnice i čitaonice „Fran Galović“ Koprivnica. // Vjesnik bibliotekara Hrvatske 58, 1/2(2015), 305319. Dostupno i na: http://hrcak.srce.hr/index.php?show=clanak\&id_clanak_jezik=211906 [citirano: 2017-04-25].

Stipanov, J. Knjižnice i društvo - od potrebe do mogućnosti. Zagreb : Školska knjiga, 2010.

Šalaj, B. Civilno društvo i demokracija: što bi Tocqueville i Putnam vidjeli u Hrvatskoj? // Anali Hrvatskog politološkog društva 8(2011), 49-71. Dostupno i na: http://hrcak. srce.hr/77758 [citirano: 2017-04-27].

Šupe, T.; D. Živković. Knjiga i čitanje u slijepe i slabovidne djece. // Vjesnik bibliotekara Hrvatske 57, 4(2014), 259-278. Dostupno i na: http://hrcak.srce.hr/index. php?show=clanak\&id_clanak_jezik=209995 [citirano: 2017-04-27].

Tkalac Verčić, A.; D. Sinčić Ćorić; N. Pološki Vokić. Priručnik za metodologiju istraživačkog rada. Zagreb : M.E.P. d.o.o., 2010.

Zakon o izmjenama i dopunama Zakona o knjižnicama. // Narodne novine 2040, 104(2000). [citirano: 2017-10-20].Dostupno na: https://narodne-novine.nn.hr/clanci/sluzbeni/2000_10_104_2040.html.

Zakon o knjižnicama. // Narodne novine 1616, 105(1997). [citirano: 2017-10-20]. Dostupno na: https://narodne-novine.nn.hr/clanci/sluzbeni/1997_10_105_1616.html.

Zakon o medijima. // Narodne novine 1324, 59(2004). [citirano: 2017-04-26]. Dostupno na: http://narodne-novine.nn.hr/clanci/sluzbeni/2004_05_59_1324.html.

Živković, D. Knjižnice na putu od poslanja do strategije: osvrt na hrvatske prilike. // Vjesnik bibliotekara Hrvatske 58, 1/2(2015), 1-14. Dostupno i na: http://hrcak.srce. $\mathrm{hr}$ /index.php?show=clanak\&id_clanak_jezik=211850 [citirano: 2017-04-25]. 